\title{
Legemiddelinteraksjoner hos pasienter i sykehjem
}

\begin{abstract}
BAKGRUNN Sykehjemspasienter behandles ofte med mange legemidler samtidig, med tilhørende økt risiko for legemiddelinteraksjoner. Målet med denne studien var å kartlegge forekomsten av legemiddelinteraksjoner hos sykehjemspasienter.
\end{abstract}

MATERIALE OG METODE Studien er basert på legemiddellister som ble samlet inn fra alle sykehjemspasienter i Trondheim kommune i løpet av én dag i 2010. Informasjonen fra legemiddellistene ble koblet opp mot den norske interaksjonsdatabasen Druid.

RESULTATER Det ble inkludert 1241 sykehjemspasienter i studien. I gjennomsnitt brukte pasientene 9,8 legemidler fast eller ved behov, med en variasjon fra 0 til 30 . I alt brukte 15 pasienter $(1,2 \%)$ legemiddelkombinasjoner som i Druid er klassifisert i gruppen «må ikke kombineres», mens $592(47,7 \%)$ brukte kombinasjoner klassifisert i gruppen «ta forholdsregler». Det var en klar sammenheng mellom antall forskrevne legemidler og risiko for interaksjoner. De tre vanligste legemiddelkombinasjonene i gruppen «må ikke kombineres» var warfarin pluss ikke-steroide antiinflammatoriske legemidler, klopidogrel pluss protonpumpehemmere og antiparkinsonmidler pluss dopaminblokkerende legemidler.

FORTOLKNING Forekomsten av alvorlige legemiddelinteraksjoner blant sykehjemspasienter i Trondheim kommune er lav. Polyfarmasi er utbredt og forekomsten av legemiddelinteraksjoner hvor det bør tas forholdsregler er høy. Da sykehjemspasienter er en utsatt gruppe med tanke på interaksjoner, bør man vurdere interaksjonsfaren spesielt nøye ved oppstart med nye legemidler.

Ved forskrivning av legemidler til eldre må man balansere flere hensyn - på den ene side har eldre mange sykdommer og plager som krever medikamentell behandling, på den annen side har de ofte endret legemiddelrespons med økt risiko for legemiddelrelaterte problemer $(1,2)$.

Omfanget av legemiddelinteraksjoner hos sykehjemspasienter $\mathrm{i}$ de nordiske land er undersøkt i flere tidligere studier. I 2008 kartla finske forskere legemiddelinteraksjoner hos 1987 sykehjemspasienter i Helsinki (3). Her fant man at over $40 \%$ av pasientene tok ni eller flere legemidler daglig og at $4,8 \%$ brukte kombinasjoner som kunne føre til klinisk signifikante legemiddelinteraksjoner. I en svensk studie fra 2010 ble kvaliteten på legemiddelforskrivningen hos 3705 sykehjemspasienter i Jönköping undersøkt (4). Her fikk $8 \%$ legemiddelkombinasjoner som burde vært unngått.

I en undersøkelse fra Bergen så man på forekomsten av interaksjoner hos pasienter som var innlagt midlertidig i sykehjem etter utskrivning fra sykehus (5). Her brukte $46,5 \%$ legemiddelkombinasjoner der det bør tas forholdsregler, mens $1,3 \%$ brukte kombinasjoner som var kontraindisert (5). I en annen sykehjemsstudie fra Bergen (6) fant man legemiddelinteraksjoner hos $48 \%$. Hos $37 \%$ forekom det interaksjoner hvor det bør tas forholdsregler, mens $1 \%$ brukte kontraindiserte kombinasjoner. Denne studien inkluderte imidlertid bare legemidler som ble dispensert i multidosepakninger, noe som medførte at blant annet warfarin, antibiotika og legemidler tatt ved behov ble ekskludert.

I de to norske studiene $(5,6)$ er det ikke redegjort for hvilke spesifikke interaksjoner som oftest forekom hos pasientene. Det er derfor behov for mer komplette og detaljerte data når det gjelder frekvens og type legemiddelinteraksjoner hos norske sykehjemspasienter. Målet med denne studien var å kartlegge forekomsten av interaksjoner hos pasienter innlagt i sykehjem og å beskrive disse interaksjonene nærmere.

\section{Materiale og metode}

Denne studien er basert på medikamentlister som ble samlet inn fra samtlige 28 institusjoner med ordinære sykehjemsplasser i Trondheim kommune 17.2. 2010. Dette omfattet i alt 1261 plasser i sykehjem, helse- og velferdssentre, omsorgssentre og helsehus. Denne dagen skrev personalet på institusjonene ut pasientenes elektroniske medikamentlister på papir. Deretter klippet de bort navnefeltet på utskriftene, før kopiene ble overlevert samlet til oss. Studien ble søkt godkjent av regional forskningsetisk komité, som anså den for å være kvalitetssikring og således ikke søknadspliktig.

Fra kopiene av medikamentlistene ble de legemidlene som hver pasient brukte fast og ved behov registrert. Polyfarmasi, som ikke er noe entydig begrep, ble i vår studie defi-

\author{
Ingvild Aune Søraas \\ Hanne Baust Staurset \\ Lars Slørdal \\ Olav Spigset \\ olav.spigset@legemidler.no \\ Institutt for laboratoriemedisin, \\ barne- og kvinnesykdommer \\ Norges teknisk-naturvitenskapelige universitet \\ og \\ Avdeling for klinisk farmakologi \\ St. Olavs hospital
}

Artikkelen er basert på en studentoppgave ved Det medisinske fakultet, Norges teknisknaturvitenskapelige universitet.

> Se lederartikkel på side 1016

\section{HOVEDBUDSKAP}

$89 \%$ av sykehjemspasientene brukte fem eller flere legemidler

$46 \%$ av sykehjemspasientene brukte ti legemidler eller mer

$1 \%$ fikk legemidler som ikke må kombineres, mens $48 \%$ brukte legemiddelkombinasjoner der det bør tas forholdsregler

Den vanligste interaksjonen klassifisert som «må ikke kombineres» var warfarin og ikke-steroide antiinflammatoriske legemidler 


\section{RAMME 1}

Klassifisering av

legemiddelinteraksjonene [9]

\section{Akademisk interesse}

Denne gruppen inneholder legemiddelinteraksjoner som er så lite uttalte at de vanligvis ikke får kliniske konsekvenser. To legemidler i denne gruppen kan derfor kombineres uten videre

\section{Ta forholdsregler}

Denne gruppen omfatter interaksjoner der det bør tas forholdsregler. Dette kan innebære å justere dosen, ta legemidlene med noen timers mellomrom, følge opp pasienten med hyppigere kliniske kontroller eller be pasienten ta kontakt hvis spesielle bivirkninger skulle oppstå. Det kan også innebære å følge opp pasienten med serumkonsentrasjonsmålinger av aktuelle legemidler eller med relevante laboratorieanalyser (INR, glukose, elektrolytter, kreatinin etc.)

\section{Må ikke kombineres}

Interaksjoner i denne gruppen kan ha så alvorlige følger for pasienten at legemiddelkombinasjonen i utgangspunktet må unngås. Dette gjelder blant annet farmakodynamiske interaksjoner med potensielt alvorlige konsekvenser luforutsigbar økning i blødningsrisiko, kramper, alvorlige hjertearytmier, m.m.) eller svært kraftige farmakokinetiske interaksjoner (i regelen minst en femdobling eller mer enn $80 \%$ reduksjon av konsentrasjonen av det legemidlet som påvirkes)

nert som bruk av fem eller flere legemidler hos en pasient $(7,8)$. For å identifisere mulige legemiddelinteraksjoner ble informasjon om hvilke legemidler hver enkelt pasient brukte koblet opp mot den norske legemiddelinteraksjonsdatabasen Druid (Drug

I denne databasen er interaksjoner kategorisert i tre grupper, «akademisk interesse», Interactions Database) (9).

«ta forholdsregler» og «må ikke kombineres» (ramme 1) (9). Antall interaksjoner i de ulike gruppene ble registrert for hver enkelt pasient, og det ble også registrert hvor ofte de ulike interaksjonene forekom i totalmaterialet. Siden data var anonymisert og ble analysert i ettertid, ble det ikke gitt tilbakemelding om interaksjoner hos enkeltpasienter. På aggregert nivå ble det imidlertid gitt tilbakemeldinger $-\mathrm{i}$ form av undervisning til sykehjemslegene i kommunen om de aktuelle funnene.

\section{Resultater}

Det totale antallet institusjonsplasser var 1261 . Den dagen studien ble gjennomført, reiste ni pasienter hjem, én ble innlagt i sykehus og én døde. Disse 11 pasientene er ikke inkludert. For ytterligere seks pasienter ble det av ukjente årsaker ikke samlet inn medikamentlister. I tillegg ble tre pasienter ekskludert $\mathrm{i}$ etterkant på grunn av ufullstendige eller usikre data. Dermed ble i alt 1241 pasienter (tilsvarende 98,4\% av alle tilgjengelige sykehjemsplasser i Trondheim) inkludert i studien - 882 kvinner (72,2\%) og 399 menn $(27,8 \%)$. Aldersspredningen var 51-104 år, med et gjennomsnitt på 84,5 år.

Alt i alt brukte 1222 pasienter $(98,5 \%)$ faste legemidler, mens 1114 (89,8\%) brukte legemidler ved behov. I gjennomsnitt brukte hvert individ 7,0 faste legemidler og 2,8 legemidler ved behov, totalt 9,8 legemidler. Antallet legemidler som pasientene tok, varierte fra 0 til 30. Polyfarmasi forekom hos $88,6 \%$ av pasientene, mens $45,6 \%$ brukte ti eller flere legemidler.

Det ble påvist potensielle interaksjoner hos 723 pasienter $(58,3 \%)$. Hos 128 av disse (10,3\% av totalmaterialet) forekom det bare interaksjoner $\mathrm{i}$ gruppen «akademisk interesse». Hos de resterende 595 (47,9\% av totalmaterialet) ble det påvist interaksjoner i gruppene «må ikke kombineres» og/eller «ta forholdsregler» (tab 1). Det var en klar sammenheng mellom antall legemidler som pasientene brukte og antall interaksjoner (fig 1).

Det ble registrert 17 legemiddelkombinasjoner i gruppen «må ikke kombineres», fordelt på 15 pasienter. Den vanligste interaksjonen i denne gruppen var mellom war-

Tabell 1 Forekomst av interaksjoner klassifisert i de to gruppene «må ikke kombineres» og «ta forholdsregler» hos 1241 sykehjemspasienter. Summen av antall pasienter i gruppene «må ikke kombineres» og «ta forholdsregler» overstiger totalantallet på 595 fordi 12 pasienter brukte legemidler som førte til interaksjoner i begge gruppene (jf. tabell 2)

\begin{tabular}{|c|c|c|}
\hline Type interaksjon & Antall pasienter (\%) & Antall interaksjoner \\
\hline Må ikke kombineres og/eller ta forholdsregler & $595 \quad(47,9)$ & 1422 \\
\hline Må ikke kombineres & $15 \quad(1,2)$ & 17 \\
\hline Ta forholdsregler & $592 \quad(47,7)$ & 1405 \\
\hline
\end{tabular}

farin og ikke-steroide antiinflammatoriske midler (NSAID) (fem pasienter). Deretter kom klopidogrel og protonpumpehemmer (fire pasienter) samt levodopa/dopaminagonist og dopaminantagonist (fire pasienter). Pasientene med interaksjoner av typen «må ikke kombineres» brukte gjennomsnittlig 13,2 legemidler, mot 9,6 i resten av populasjonen.

De vanligst forekommende legemiddelkombinasjonene i gruppen «ta forholdsregler» var opioider pluss benzodiazepiner $(23,1 \%)$, warfarin pluss paracetamol $(11,2 \%)$ og acetylsalisylsyre pluss selektive serotoninreopptakshemmere (SSRI) $(8,4 \%)$. Interaksjoner av denne typen som forekom hos minst $1 \%$ av pasientene, er oppført i tabell 2 .

Hos i alt 72 pasienter $(5,8 \%)$ ble det påvist fem eller flere interaksjoner klassifisert som «må ikke kombineres» eller «ta forholdsregler» (fig 2). Det høyeste antallet hos én pasient var 11 interaksjoner. Videre forekom det fire slike interaksjoner hos $3,1 \%$, tre slike interaksjoner hos $6,8 \%$, to slike interaksjoner hos $11,7 \%$ og én slik interaksjon hos $20,5 \%$ av pasientene.

\section{Diskusjon}

Hovedfunnet i denne studien er at $1,2 \%$ av pasientene brukte legemiddelkombinasjoner av typen «må ikke kombineres», mens $47,7 \%$ brukte kombinasjoner av typen «ta forholdsregler». Selv om det er langt mer uvanlig at det oppstår ugunstige effekter av interaksjoner i sistnevnte kategori, kan de være vel så viktige når det gjelder konsekvensene sett i et populasjonsperspektiv. Polyfarmasi forkom hos $88,6 \%$ av pasientene, og $45,5 \%$ tok ti eller flere medikamenter daglig. Gjennomsnittlig antall legemidler $\operatorname{var} 9,8$.

Antallet legemidler er noe høyere enn i tidligere studier fra sykehjem i Finland og Norge, hvor det i gjennomsnitt ble brukt henholdsvis 7,9 og 5,7 legemidler $(3,6)$. Forskjellen kan delvis forklares med at vi, i motsetning til det som ble gjort $i$ de tidligere studiene, også inkluderte legemidler tatt ved behov, som i gjennomsnitt var 2,8 per pasient. Sammenliknet med en annen studie der man også inkluderte behovslegemidler og som bygde på data fra åtte europeiske land (10), er likevel våre tall høye. Én forklaring på dette kan være økende bruk av flermedikamentelle regimer $\mathrm{i}$ behandlingen av vanlige tilstander hos eldre, som for eksempel hjerte- og karsykdommer.

Med økende antall legemidler øker også faren for interaksjoner (11). I en tidligere studie fant man at antall legemidler hos en og samme pasient var assosiert med en eksponentiell økning i antall legemiddelinteraksjoner (12). Det var en klar tendens til det samme i vår studie (fig 1). Dette tyder på at 
det å redusere antall legemidler hos enkeltpasienter i seg selv vil kunne ha interaksjonsforebyggende effekter.

Det må imidlertid påpekes at selv om risikoen for legemiddelinteraksjoner er økt hos pasienter som tar mange legemidler, er ikke nødvendigvis alltid polyfarmasi hos eldre uheldig. Mennesker i høy alder har ofte mange kroniske sykdommer, noe som øker behovet for flere legemidler (13). Dessuten kan behandling med flere legemidler for én enkelt sykdom være positivt når kombinasjonen har en additiv terapeutisk effekt. Samtidig kan bivirkningene av enkeltpreparatene bli mindre fordi dosen av hvert legemiddel holdes lavere (14).

I den europeiske studien som er referert over (10), var det en direkte sammenheng mellom grad av symptomplager og antall legemidler. Dette kan peke i retning av at symptomlindring er et viktig behandlingsmål i sykehjem og at økt livskvalitet er prioritert, selv om det medfører risiko for polyfarmasi og interaksjoner. Det er dessuten viktig å huske at pasientene $i$ vår studie hadde døgnkontinuerlig tilsyn fra helsepersonell. Man har dermed muligheten til å følge dem tett, noe som kan gi mindre risiko for alvorlige konsekvenser enn om de hadde bodd hjemme.

Vi gjorde ikke noen generell gjennomgang av bruken av legemidler hos vår populasjon. Siden vi ikke hadde informasjon om indikasjon eller andre kliniske data, kunne vi ikke bruke beslutningsverktøy som STOPP (Screening tool of older persons' potentially inappropriate prescriptions) (15) for å vurdere eventuell uhensiktsmessig legemiddelbruk hos våre pasienter.

Våre resultater når det gjelder frekvensen av interaksjonene likner funn gjort i to tidligere norske studier $(5,6)$. I den ene av disse (5) fant man at $1,3 \%$ av individene brukte kontraindiserte kombinasjoner og at 46,5\% brukte kombinasjoner hvor det bør tas forholdsregler. I den andre (6) brukte $1 \%$ legemidler som ikke må kombineres og $37 \%$ fikk kombinasjoner hvor det bør tas forholdsregler.

Forekomsten av kontraindiserte legemiddelkombinasjoner er noe lavere $\mathrm{i}$ vår studie enn i studier fra Sverige og Finland $(3,4)$, der henholdsvis $8 \%$ og $4,8 \%$ av pasientene fikk slike kombinasjoner. Dette kan skyldes økt oppmerksomhet omkring uheldig legemiddelbruk de siste årene, men det kan muligens også henge sammen med hvilke legemiddelkombinasjoner som er inkludert og hvordan de er klassifisert i ulike nasjonale interaksjonsdatabaser.

Som vist $\mathrm{i}$ tabell 2 og figur 2 fant vi 17 legemiddelkombinasjoner av sju prinsipielt ulike typer i gruppen «må ikke kombineres». Hvor farlig er det egentlig å bruke disse

\section{Gjennomsnittlig antall interaksjoner}

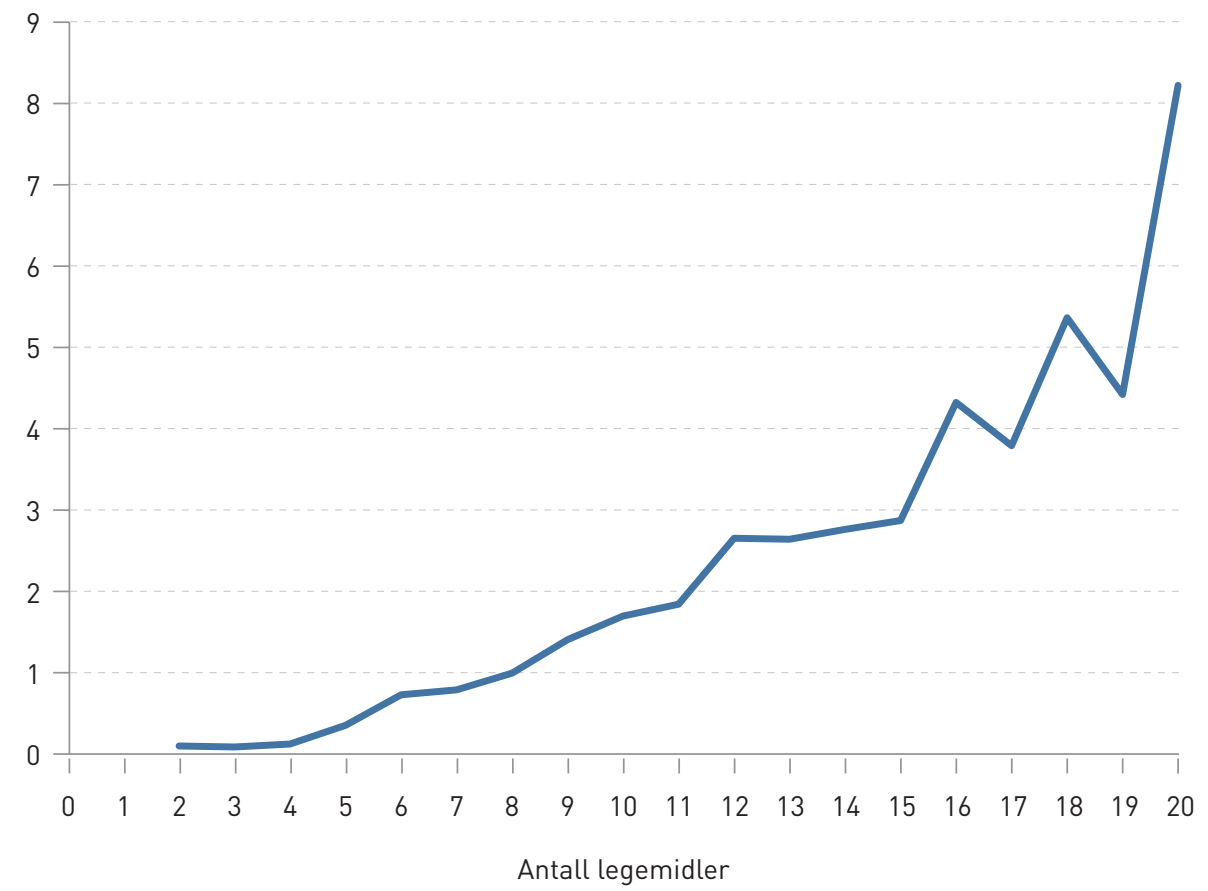

Figur 1 Sammenheng mellom antall legemidler forskrevet og antall legemiddelinteraksjoner hos 1241 sykehjemspasienter

Antall individer

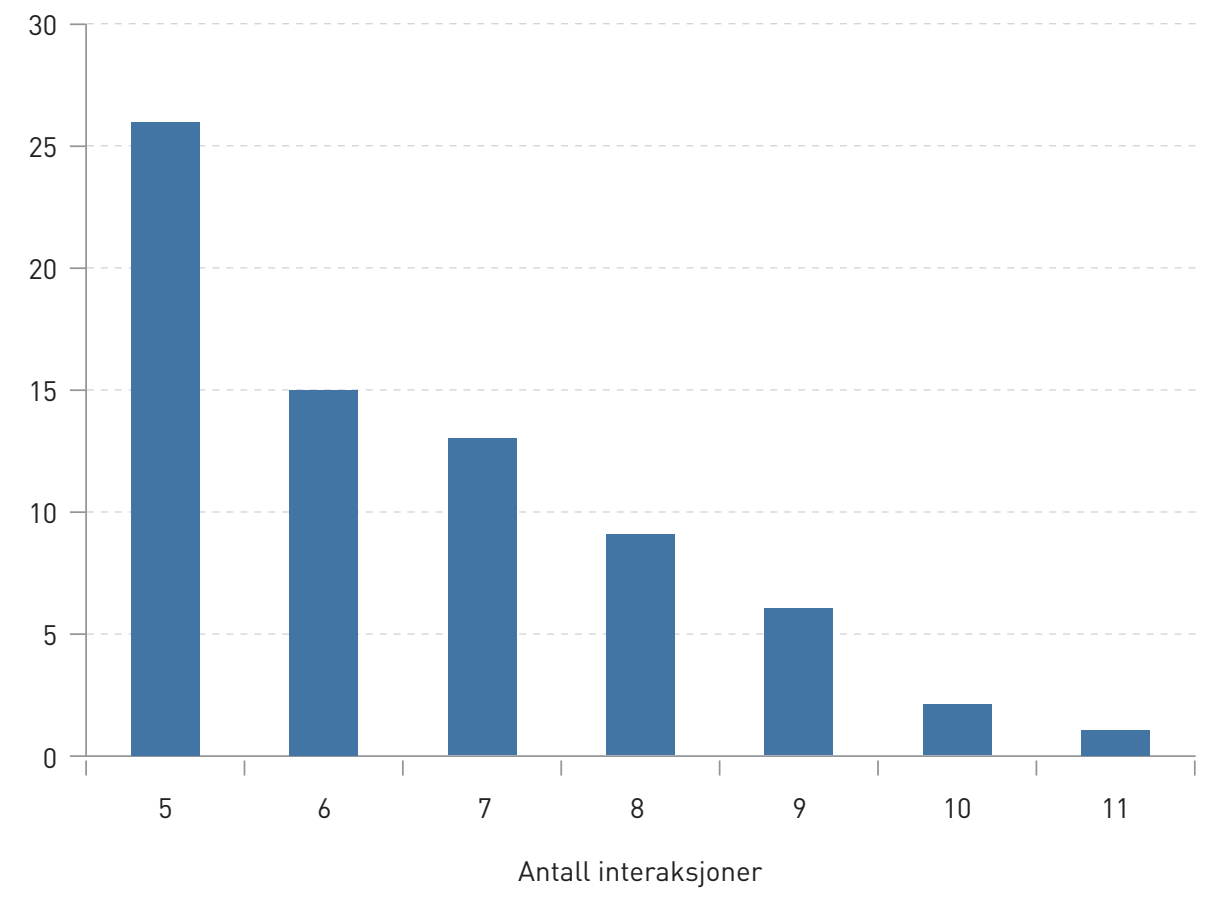

Figur 2 Antall pasienter hvor det ble påvist fem eller flere legemiddelinteraksjoner klassifisert i gruppene «må ikke kombineres» eller «ta forholdsregler» 
Tabell 2 Alle interaksjoner i gruppen «må ikke kombineres»

\begin{tabular}{|c|c|c|c|c|}
\hline $\begin{array}{l}\text { Legemiddel } 1 \\
\text { (fast/ved behov, } \\
\text { daglig dose) }\end{array}$ & $\begin{array}{l}\text { Legemiddel } 2 \\
\text { (fast/ved behov, } \\
\text { daglig dose) }\end{array}$ & Mulig klinisk konsekvens & $\begin{array}{l}\text { Antall } \\
\text { legemidler } \\
\text { totalt hos } \\
\text { pasienten }\end{array}$ & $\begin{array}{l}\text { Antall interak- } \\
\text { sjoner i gruppen } \\
\text { «ta forholdsregler» } \\
\text { hos pasienten }\end{array}$ \\
\hline Warfarin (fast) & Vitamin K (fast) & Antagonistisk effekt & \multirow{2}{*}{9} & \multirow{2}{*}{3} \\
\hline Warfarin (fast) & Diklofenak (fast, 150 mg) & $\emptyset k t$ blødningsrisiko & & \\
\hline Pramipeksol (fast, 0,26 mg) & Metoklopramid (ved behov) & Forverret Parkinsons sykdom & \multirow[b]{2}{*}{24} & \multirow[b]{2}{*}{6} \\
\hline Warfarin (fast) & Ibuprofen (ved behov) & $\emptyset k t$ blødningsrisiko & & \\
\hline Warfarin (fast) & Ibuprofen (fast, 600 mg) & $\emptyset k t$ blødningsrisiko & 9 & 5 \\
\hline Warfarin (fast) & Ibuprofen (ved behov) & $\emptyset k t$ blødningsrisiko & 13 & 8 \\
\hline Warfarin (fast) & Ibuprofen (ved behov) & $\emptyset k t$ blødningsrisiko & 12 & 2 \\
\hline Klopidogrel (fast, 75 mg) & Omeprazol (fast, $20 \mathrm{mg}$ ) & $\begin{array}{l}\text { Nedsatt konsentrasjon av aktiv metabolitt, } \\
\text { risiko for redusert klinisk effekt av klopidogrel }\end{array}$ & 9 & 0 \\
\hline Klopidogrel (fast, 75 mg) & Esomeprazol (fast, $20 \mathrm{mg}$ ) & $\begin{array}{l}\text { Nedsatt konsentrasjon av aktiv metabolitt, } \\
\text { risiko for redusert klinisk effekt av klopidogrel }\end{array}$ & 12 & 0 \\
\hline Klopidogrel (fast, 75 mg) & Esomeprazol (fast, $40 \mathrm{mg}$ ) & $\begin{array}{l}\text { Nedsatt konsentrasjon av aktiv metabolitt, } \\
\text { risiko for redusert klinisk effekt av klopidogrel }\end{array}$ & 16 & 4 \\
\hline Klopidogrel (fast, 75 mg) & Lansoprazol (fast, 30 mg) & $\begin{array}{l}\text { Nedsatt konsentrasjon av aktiv metabolitt, } \\
\varnothing k t \text { risiko for redusert klinisk effekt av klopidogrel }\end{array}$ & 12 & 1 \\
\hline $\begin{array}{l}\text { Levodopa og dekarboksyl- } \\
\text { asehemmer (fast } 2 \text { tabletter) }\end{array}$ & Risperidon (fast, 0,5 mg) & Gjensidig nedsatt effekt & 13 & 1 \\
\hline $\begin{array}{l}\text { Levodopa og dekarboksyla- } \\
\text { sehemmer (fast, } 3 \text { tabletter) }\end{array}$ & Haloperidol (fast, 1 mg) & Gjensidig nedsatt effekt & 12 & 2 \\
\hline Pramipeksol (fast, 0,09 mg) & Risperidon (fast, 0,5 mg) & Forverret Parkinsons sykdom & 13 & 2 \\
\hline Fluoksetin (fast, 20 mg) & Metoprolol (fast, 100 mg) & $\begin{array}{l}\emptyset \mathrm{kt} \text { konsentrasjon av metoprolol, økt risiko } \\
\text { for bivirkninger (lav puls, slapphet, svimmelhet) }\end{array}$ & 12 & 0 \\
\hline Fenelzin (fast, $30 \mathrm{mg}$ ) & $\begin{array}{l}\text { Levomepromazin } \\
\text { (ved behov) }\end{array}$ & Risiko for alvorlige bivirkninger & 18 & 1 \\
\hline Metenamin (fast, $2000 \mathrm{mg}$ ) & $\begin{array}{l}\text { Sulfametoksazol og trime- } \\
\text { toprim (fast, } 4 \text { tabletter) }\end{array}$ & Risiko for utfelling av krystaller i urinveiene & 12 & 2 \\
\hline
\end{tabular}

kombinasjonene? Den vanligste kontraindiserte kombinasjonen var warfarin og et ikkesteroid antiinflammatorisk middel. Samtidig bruk av disse øker blødningsrisikoen betydelig, spesielt hos eldre. I en studie fant man at kombinasjonen økte risikoen for blødende magesår med en faktor på fire sammenliknet med bruk av ett av midlene og med en faktor på 12 i forhold til ikke å bruke noen av midlene (16).

Bruk av antipsykotika kombinert med levodopa eller dopaminagonister frarådes grunnet antagonistiske effekter på reseptornivå. Antipsykotika og det kvalmestillende midlet metoklopramid er dopamin $\mathrm{D}_{2}$-antagonister og vil dermed motvirke effekten av legemidlene mot Parkinsons sykdom.

Hos noen pasienter som behandles med platehemmere, er det anbefalt å bruke en protonpumpehemmer for å redusere risikoen for blødning fra mage-tarm-kanalen (17). Klopidogrel er inaktivt og omdannes til aktiv metabolitt via enzymet CYP2C19. Dette enzymet hemmes av omeprazol og esomeprazol. Resultatet kan bli nedsatt konsentrasjon av den aktive klopidogrelmetabolitten og terapisvikt. Til tross for at kombinasjonen frarådes, er den kliniske relevansen av interaksjonen omdiskutert (17). Farmakologisk sett vil det likevel være tryggest å velge pantoprazol som protonpumpehemmer, siden dette midlet gir minst CYP2C19hemming.

Antidepressiver som er kraftige hemmere av enzymet CYP2D6, vil øke plasmakonsentrasjonen av metoprolol betydelig (18), og paroksetin og fluoksetin kan øke metoprololnivåene med en faktor på 4-6. Det vil si at en pasient som behandles med en døgndose på $100 \mathrm{mg}$ metoprolol kombinert med
$20 \mathrm{mg}$ fluoksetin, vil få like høye plasmanivåer som ved inntak av 400-600 mg metoprolol per dag. I kasuistikker er det blant annet beskrevet alvorlige bivirkninger som AV-blokk grad III og uttalt bradykardi når metoprolol er blitt kombinert med fluoksetin eller paroksetin (18).

Warfarin frarådes brukt i kombinasjon med vitamin $\mathrm{K}$ grunnet den antagonistiske effekten. I enkelte tilfeller, som ved atrieflimmer og samtidig malabsorpsjon eller gallestase, kan kombinasjonen likevel være nødvendig. Dette innebærer en oppjustering av warfarindosen. Det er da viktig at dosen av vitamin $\mathrm{K}$ ikke endres uten videre, siden dette kan føre til overdosering eller underdosering av warfarin (19).

De tre vanligste kombinasjonene i gruppen «ta forholdsregler» var opioider pluss benzodiazepiner, acetylsalisylsyre pluss 
Tabell 3 Interaksjoner i gruppen «ta forholdsregler» som forekom hos minst $1 \%$ av 1241 sykehjemspasienter

\begin{tabular}{lcc}
\hline Interaksjon & Antall & Prosent \\
Opioider - benzodiazepiner & 287 & 23,1 \\
Warfarin - paracetamol & 139 & 11,2 \\
Acetylsalisylsyre - selektive serotoninreopptakshemmere & 104 & 8,4 \\
Warfarin - laktulose & 72 & 5,8 \\
Digitalisglykosider - diuretika & 46 & 3,7 \\
Warfarin - selektive serotoninreopptakshemmere & 44 & 3,5 \\
Bisfosfonater - kalsium & 42 & 3,4 \\
Warfarin - antibiotika & 34 & 2,7 \\
Escitalopram - metoprolol & 29 & 2,3 \\
Levotyroksin - kalsiumkarbonat & 28 & 2,3 \\
Acetylsalisylsyre - ibuprofen & 23 & 1,9 \\
Selektive serotoninreopptakshemmere - NSAID-midler & 23 & 1,9 \\
Diuretika - NSAID-midler & 22 & 1,8 \\
Citalopram - metoprolol & 21 & 1,7 \\
Midler til diabetesbehandling - ACE-hemmere & 17 & 1,4 \\
Warfarin - thyreoideapreparater & 16 & 1,3 \\
Betablokkere - antikolinesteraser & 15 & 1,2 \\
Selektive serotoninreopptakshemmere - tramadol & 15 & 1,2 \\
Warfarin - tramadol & 15 \\
Betablokkere - NSAID-midler & 15 \\
\hline
\end{tabular}

selektive serotoninreopptakshemmere og warfarin pluss paracetamol. Kombinert bruk av opioider og benzodiazepiner vil kunne gi kraftig sentralnervøs demping, med risiko for betydelig sedasjon og eventuelt også respirasjonshemming (20). Det er vist at selektive serotoninreopptakshemmere sammen med acetylsalisylsyre vil gi økt risiko for blødning fra mage-tarm-kanalen (21).

Bruk av paracetamol hos pasienter som behandles med warfarin kan øke effekten av sistnevnte. I en studie økte paracetamol i dosen $1 \mathrm{~g}$ fire ganger daglig INR-verdien allerede fra dag 2 (22). Deretter fortsatte økningen inntil en stabilt høyere INR-verdi ble nådd etter en ukes tid. Ved fast bruk av paracetamol kan man kompensere for dette ved å justere warfarindosen, men dersom paracetamol bare brukes i korte perioder, kan det føre til mer uforutsigbare svingninger i INR-verdien.

Denne studien har noen svakheter som må nevnes. Vi hadde ikke tilgang til informasjon om pasientenes tilstand og diagnoser og hadde heller ikke kjennskap til eventuelle kliniske vurderinger gjort ved start av legemiddelbehandlingen. En konsekvens av dette er usikkerhet rundt hvorvidt aktuelle forholdsregler var tatt ved forskrivning av potensielt interagerende legemidler. Videre hadde vi ikke mulighet til å studere eventuelle utfall av interaksjonene. Vi kan derfor ikke si noe om de ugunstige effektene som interaksjonene kan gi, hadde manifestert seg hos pasientene.

Det er ulik praksis når det gjelder å inkludere behovsmedisin i interaksjonsstudier. Vi valgte å ta med ethvert medikament pasienten kan ha blitt eksponert for den aktuelle dagen, uavhengig om det er tatt fast eller ved behov. Dette gir etter vår oppfatning et mer helhetlig bilde av den totale interaksjonsrisikoen pasientene er utsatt for. Som vist i eksemplene med warfarin kombinert med paracetamol og med vitamin $\mathrm{K}$ vil dessuten uregelmessig inntak gi mer fluktuerende og uforutsigbare følger enn fast bruk.

Materialet vårt er relativt stort $(n=1241)$ og - med en deltakelse på 98,4 \% - nærmest komplett. Selv om deltakerprosenten er svært høy, kan man spørre om funnene er representative for situasjonen nasjonalt. Alle institusjonene tilhørte Trondheim kommune, og legemiddelbruken kan være farget av lokale rutiner og terapitradisjoner. At våre funn ikke er vesensforskjellig fra funn $\mathrm{i}$ andre norske studier $(5,6)$, gir imidlertid grunn til å tro at opplæring og rutiner ikke er særlig annerledes i Trondheim enn andre steder i landet.

I og med at data ble manuelt overført fra kopiene av legemiddellistene, kan det ha oppstått feilregistreringer. For å ta høyde for dette, ble alle data nøye kontrollert. Etter koblingen mot Druid ble resultatene gjennomgått enda en gang. Vi har også undersøkt om og i så fall på hvilken måte de interaksjonene som ble påvist $i$ vårt materiale var omtalt $\mathrm{i}$ et internasjonalt referanseverk om legemiddelinteraksjoner (23). Vi fant ingen uoverensstemmelser av betydning for dette materialet.

I en klinisk hverdag er det vanskelig, for ikke å si umulig, å ha oversikt over alle interaksjoner som kan oppstå. Det kan derfor være nyttig å bruke elektroniske interaksjonsverktøy rutinemessig. Databasen Druid er nå overtatt av Statens legemiddelverk som en del av Forskrivnings- og ekspedisjonsstøtte (FEST), som også leverer interaksjonsdata til e-resept og til elektroniske journalsystemer i allmennpraksis og sykehus (24). I tillegg får man tilgang til ulike interaksjonsdatabaser via Helsebiblioteket.no $(25,26)$.

Systematisk bruk av interaksjonsdatabaser og kritisk gjennomgang av medikamentlister kan hindre potensielt farlige interaksjoner, samtidig som det kan redusere det totale antallet legemidler $(27,28)$ og dermed øke kvaliteten på behandlingen.

Vi takker Magne Rekdal for utmerket teknisk bistand med kobling mot interaksjonsdatabasen Druid og Brita Bjørnseth og personalet på sykehjemmene for praktisk hjelp i forbindelse med innsamling av legemiddellistene.

\section{Ingvild Aune Søraas (f. 1988)}

er medisinstudent ved Norges teknisk-naturvitenskapelige universitet.

Forfatter har fylt ut ICMJE-skjemaet og oppgir ingen interessekonflikter.

\section{Hanne Baust Staurset (f. 1989)}

er medisinstudent ved Norges teknisk-naturvitenskapelige universitet.

Forfatter har fylt ut ICMJE-skjemaet og oppgir ingen interessekonflikter. 


\section{Lars Slørdal (f. 1955)}

er professor i farmakologi ved Norges teknisknaturvitenskapelige universitet og overlege ved Avdeling for klinisk farmakologi, St. Olavs hospital.

Forfatter har fylt ut ICMJE-skjemaet og oppgir ingen interessekonflikter.

\section{Olav Spigset (f. 1963)}

er overlege ved Avdeling for klinisk farmakologi, St. Olavs hospital, og professor i klinisk farmakologi ved Norges teknisk-naturvitenskapelige universitet.

Forfatter har fylt ut ICMJE-skjemaet og oppgir følgende interessekonflikter: Han har vært faglig ansvarlig for interaksjonsdatabasen Druid og er en av de faglige redaktørene for interaksjonsmodulen i FEST. Han har mottatt honorar for disse oppdragene.

\section{Litteratur}

1. Mangoni AA, Jackson SH. Age-related changes in pharmacokinetics and pharmacodynamics: basic principles and practical applications. Br J Clin Pharmacol 2004; 57: 6-14.

2. Gallagher P, Barry P, O'Mahony D. Inappropriate prescribing in the elderly. J Clin Pharm Ther 2007; 32: 113-21.

3. Hosia-Randell HM, Muurinen SM, Pitkälä KH. Exposure to potentially inappropriate drugs and drug-drug interactions in elderly nursing home residents in Helsinki, Finland: a cross-sectional study. Drugs Aging 2008; 25: 683-92.

4. Olsson J, Bergman A, Carlsten A et al. Quality of drug prescribing in elderly people in nursing homes and special care units for dementia: a cross-sectional computerized pharmacy register analysis. Clin Drug Investig 2010; 30: 289-300

5. Bakken MS, Ranhoff AH, Engeland A et al. Inappropriate prescribing for older people admitted to an intermediate-care nursing home unit and hospital wards. Scand J Prim Health Care 2012; 30: $169-75$

6. Halvorsen KH, Granås AG, Engeland A et al. Prescribing quality for older people in Norwegian nursing homes and home nursing services using multidose dispensed drugs. Pharmacoepidemiol Drug Saf 2012; 21: 929-36.

7. Junius-Walker U, Theile G, Hummers-Pradier E. Prevalence and predictors of polypharmacy among older primary care patients in Germany. Fam Pract 2007; 24: 14-9.

8. Hovstadius B, Hovstadius K, Åstrand B et al. Increasing polypharmacy - an individual-based study of the Swedish population 2005-2008. BMC Clin Pharmacol 2010; 10: 16

9 Interaksjonsdatabase for norske klinikere. www.interaksjoner.no (12.4.2012).

10. Onder G, Liperoti R, Fialova D et al. Polypharmacy in nursing home in Europe: results from the SHELTER study. J Gerontol A Biol Sci Med Sci 2012; 67: 698-704.

11. Radosević N, Gantumur M, Vlahović-Palcevski V. Potentially inappropriate prescribing to hospitalised patients. Pharmacoepidemiol Drug Saf 2008 17: $733-7$.

12. Goldberg RM, Mabee J, Chan L et al. Drug-drug and drug-disease interactions in the ED: analysis of a high-risk population. Am J Emerg Med 1996; 14: 447-50.

13. Ineke Neutel C, Skurtveit S, Berg C. Polypharmacy of potentially addictive medication in the older persons-quantifying usage. Pharmacoepidemiol Drug Saf 2012; 21: 199-206.

14. Law MR, Wald NJ, Morris JK et al. Value of low dose combination treatment with blood pressure lowering drugs: analysis of 354 randomised trials. BMJ 2003; 326: 1427.

15. Bjørnestad EØ, Ranhoff AH. STOPP uhensiktsmessig legemiddelbruk hos eldre. Tidsskr Nor Legeforen 2013: 133: 1175

16. Shorr RI, Ray WA, Daugherty JR et al. Concurrent use of nonsteroidal anti-inflammatory drugs and oral anticoagulants places elderly persons at high risk for hemorrhagic peptic ulcer disease. Arch Intern Med 1993; 153: 1665-70.

17. Drepper MD, Spahr L, Frossard JL. Clopidogrel and proton pump inhibitors - where do we stand in 2012? World J Gastroenterol 2012; 18: $2161-71$.
18. Molden E, Spigset O. Interaksjoner mellom metoprolol og antidepressive legemidler. Tidsskr Nor Legeforen 2011: 131: 1777-9.

19. Melien $\emptyset$, Johansen PW, Westergren T et al. Vitamin K i matvarer og effekt av warfarin. Tidsskr Nor Lægeforen 2003; 123: 1862-3.

20. Patel S, Vargo JJ, Khandwala F et al. Deep sedation occurs frequently during elective endoscopy with meperidine and midazolam. Am J Gastroenterol 2005; 100: 2689-95.

21. Dalton SO, Johansen C, Mellemkjaer L et al. Use of selective serotonin reuptake inhibitors and risk of upper gastrointestinal tract bleeding: a population-based cohort study. Arch Intern Med 2003: 163: 59-64.

22. Mahé I, Bertrand N, Drouet L et al. Interaction between paracetamol and warfarin in patients: a double-blind, placebo-controlled, randomized study. Haematologica 2006; 91: 1621-7.

23. Baxter K, red. Stockley's drug interactions. London: The Pharmaceutical Press, 2010.

24. Statens legemiddelverk. Forskrivnings- og ekspe disjonsstøtte (FEST). www.legemiddelverket.no/ Bruk_og_raad/FEST/Sider/default.aspx (13.5.2013).

25. Helsebiblioteket. Emnebibliotek legemidler, interaksjoner hurtigverktøy. www. helsebiblioteket.no/ legemidler/legemiddeleffekter/ interaksjoner-hurtigverkt\%c3\%b8y (2.2.2014).

26. Helsebiblioteket. Micromedex i Helsebiblioteket fra januar 2014. www. helsebiblioteket.no/ nyhetsarkiv/micromedex-i-helsebiblioteket-frajanuar-2014 (2.2.2014).

27. Andersson ML, Böttiger Y, Lindh JD et al. Impact of the drug-drug interaction database SFINX on prevalence of potentially serious drug-drug interactions in primary health care. Eur J Clin Pharmacol 2013; 69: 565-71.

28. Helsedirektoratet. IS-1998. Veileder om legemiddelgjennomganger. Oslo, 2012 www.helsedirektoratet.no/publikasjoner/ veileder-om-legemiddelgjennomganger/Sider/ default.aspx (13.5 2013).

Mottatt 2.12. 2013, første revisjon innsendt 5.2 . 2014, godkjent 6.3. 2014. Redaktør: Are Brean. 